\title{
Thiovirga sulfuroxydans gen. nov., sp. nov., a chemolithoautotrophic sulfur-oxidizing bacterium isolated from a microaerobic waste-water biofilm
}

\author{
Correspondence \\ Satoshi Okabe \\ sokabe@eng.hokudai.ac.jp
}

\author{
Tsukasa Ito, ${ }^{1}$ Kenichi Sugita, ${ }^{1}$ Isao Yumoto, ${ }^{2}$ Yoshinobu Nodasaka ${ }^{3}$ \\ and Satoshi Okabe ${ }^{1}$
}
${ }^{1}$ Department of Urban and Environmental Engineering, Graduate School of Engineering, Hokkaido University, Kita-ku, Sapporo 060-8628, Japan
${ }^{2}$ Research Institute of Biological Resources and Function, Hokkaido Center, National Institute of Advanced Industrial Science and Technology, Tsukisamu-Higashi, Toyohira-ku, Sapporo 062-8517, Japan
${ }^{3}$ Laboratory of Electron Microscopy, Graduate School of Dental Medicine, Hokkaido University, Kita-ku, Sapporo 060-8586, Japan

\begin{abstract}
A novel mesophilic, chemolithoautotrophic, sulfur-oxidizing bacterium, designated strain $\mathrm{SO}^{\top}{ }^{\top}$, was isolated from a microaerobic waste-water biofilm. Chemolithoautotrophic growth was observed with elemental sulfur, sulfide and thiosulfate as sole electron donors and oxygen as electron acceptor. Anaerobic and heterotrophic growth were not observed. Nitrate was not used as a terminal electron acceptor. The optimum $\mathrm{pH}$ and temperature for growth were $\mathrm{pH} 7.5$ and $30{ }^{\circ} \mathrm{C}$, respectively. The major isoprenoid quinone was $\mathrm{Q}-8$. The DNA G $+\mathrm{C}$ content of strain $\mathrm{SO}^{\top}{ }^{\top}$ was $47 \cdot 1 \mathrm{~mol} \%$. Phylogenetic analysis of $16 \mathrm{~S}$ rRNA gene sequences demonstrated that strain $\mathrm{SO}^{\top}{ }^{\top}$ formed a monophyletic group in the $\gamma$-Proteobacteria with only $89 \%$ similarity to members of the genus Halothiobacillus, its nearest phylogenetic neighbours. In addition, the isolate differed from members of the genus Halothiobacillus in its requirement for and tolerance of $\mathrm{NaCl}$; strain $\mathrm{SO}^{\top}{ }^{\top}$ was unable to grow in $\mathrm{NaCl}$ concentrations of more than $180 \mathrm{mM}$. On the basis of phylogenetic, chemotaxonomic and physiological data, it is proposed that isolate $\mathrm{SOO}^{\top}\left(=\mathrm{JCM} 12417^{\top}=\right.$ ATCC BAA-1033 $\left.{ }^{\top}\right)$ represents the type strain of a novel species in a new genus, Thiovirga sulfuroxydans gen. nov., sp. nov.
\end{abstract}

During investigations into the sulfur cycle in a microaerobic waste-water biofilm, a survey combining the molecular techniques of 16S rRNA gene cloning followed by fluorescence in situ hybridization revealed the presence of a novel sulfur-oxidizing bacterium (approximately $10^{8}$ cells $\mathrm{cm}^{-3}$ ), designated strain $\mathrm{SO} 07^{\mathrm{T}}$, which was present at the oxic biofilm strata where high concentrations of elemental sulfur $\left(S^{0}\right)$ accumulate. The use of $S^{0}$ as an electron donor was an effective measure to establish an enrichment culture of strain $\mathrm{SO}_{0} 7^{\mathrm{T}}$ and for further purification (Ito et al., 2004). The $16 \mathrm{~S}$ rRNA genes of large numbers of uncultured bacterial clones that are closely related to strain $\mathrm{SO} 07^{\mathrm{T}}$ have been found in GenBank (Benson et al., 2003), suggesting the widespread distribution and ecological

Published online ahead of print on 9 December 2004 as DOI 10.1099/ ijs.0.63467-0.

Abbreviation: EDS, energy-dispersive X-ray spectroscopy.

The GenBank/EMBL/DDBJ accession number for the 16S rRNA gene sequence of Thiovirga sulfuroxydans $\mathrm{SOO}^{\top}$ is $\mathrm{AB} 118236$. importance of these types of bacteria in the environment. Analysis of phylogenetic and physiological characteristics showed that strain $\mathrm{SO}_{0} 7^{\mathrm{T}}$ represents the type strain of the type species of a new genus; the name Thiovirga sulfuroxydans gen. nov., sp. nov. is proposed.

The waste-water biofilm sample was collected from a sewer line that transports primary settling tank effluent at the Soseigawa municipal waste-water treatment plant, Sapporo, Japan. Enrichment and isolation were performed using a slightly modified version of medium used for neutrophilic Thiobacillus species (Kuenen et al., 1991), designated SOB medium in this study. The composition of SOB medium (in $\mathrm{g} \mathrm{l}^{-1}$ ) was $\mathrm{KH}_{2} \mathrm{PO}_{4}(0 \cdot 5), \mathrm{K}_{2} \mathrm{HPO}_{4}(0 \cdot 5), \mathrm{NH}_{4} \mathrm{Cl}(0 \cdot 5)$, $\mathrm{MgSO}_{4} \cdot 7 \mathrm{H}_{2} \mathrm{O}(0 \cdot 1), \mathrm{CaCl}_{2}(0 \cdot 05)$ and $\mathrm{NaHCO}_{3}(1 \cdot 0)$, plus $1 \mathrm{ml}$ trace element solution $\mathrm{l}^{-1}$ (Kuenen et al., 1991). The procedures for enrichment and isolation have been described previously (Ito et al., 2004). Cells grown in liquid SOB medium with thiosulfate $(6.5 \mathrm{mM})$ as a sole electron donor were used for studies on phenotypic properties and chemotaxonomic traits unless otherwise specified. Aerobic 
growth was examined in SOB medium supplemented with sulfide $(13 \mathrm{mM})$, thiosulfate $(6.5 \mathrm{mM})$, elemental sulfur $\left(416 \mathrm{mg} \mathrm{l}^{-1}\right)$, methanol $(1 \mathrm{mM})$, formate $(1 \mathrm{mM})$, acetate $(1 \mathrm{mM})$ or propionate $(1 \mathrm{mM})$ as electron donor. Anaerobic growth was examined in SOB medium containing the same electron donors as in the aerobic growth test and with nitrate $(0.74 \mathrm{mM})$ as electron acceptor; the headspace gas contained only $\mathrm{N}_{2}$ gas $(99 \cdot 99 \%$, v/v). Fermentative growth was tested in SOB medium containing the same electron donors as in the aerobic growth test under anoxic conditions without nitrate. Mixotrophic growth was tested in SOB medium containing thiosulfate $(6.5 \mathrm{mM})$ together with one of formate $(13 \mathrm{mM})$, acetate $(13 \mathrm{mM})$ or propionate $(13 \mathrm{mM})$. Substrate utilization was evaluated by measuring each substrate concentration and by DAPI direct counting as described by Hobbie et al. (1977). The concentrations of sulfate, thiosulfate, nitrite, nitrate, formate, acetate and propionate in the culture solutions were determined with an ion chromatograph equipped with either an IonPac AS9-HCC column for sulfate, thiosulfate, nitrite and nitrate or an ICE-AS1 column for formate, acetate and propionate (model DX-100; Nippon Dionex). The concentration of total dissolved sulfide $\left(\mathrm{H}_{2} \mathrm{~S}, \mathrm{HS}^{-}\right.$and $\mathrm{S}^{2-}$ ) was determined by the methylene blue method (Cline, 1969). The temperature range for growth was examined in SOB medium containing thiosulfate $(6.5 \mathrm{mM})$ at $5,10,15$, $20,25,30,34,37,42,47$ and $55^{\circ} \mathrm{C}$. The $\mathrm{pH}$ range for growth $(4 \cdot 0-10 \cdot 0)$ was tested in SOB medium containing thiosulfate at $30^{\circ} \mathrm{C}$. The $\mathrm{NaCl}$ requirement and tolerance of the isolate were examined in $\mathrm{SOB}$ medium containing various $\mathrm{NaCl}$ concentrations $(0 \cdot 03,0 \cdot 08,0 \cdot 13,0 \cdot 18,0 \cdot 23,1 \cdot 0,2 \cdot 0$, 3.0 and $4.0 \mathrm{M}$ ). Growth of strain $\mathrm{SO}^{\mathrm{T}}$ was monitored by measuring the optical density at $540 \mathrm{~nm}$. All the growth tests described above were conducted at $30^{\circ} \mathrm{C}$ and $\mathrm{pH} 7 \cdot 0$ unless otherwise specified.

For morphological observations, cells grown on solid SOB medium containing $1.5 \%$ agar at $25^{\circ} \mathrm{C}$ for 1 day were negatively stained with $1 \%(\mathrm{w} / \mathrm{v})$ phosphotungstic acid and then observed under a Hitachi model H-800 transmission electron microscope at an acceleration voltage of $75 \mathrm{kV}$. For ultrastructure analysis, cells grown on SOB agar medium were immersed in $2 \%(\mathrm{v} / \mathrm{v})$ glutaraldehyde in $0 \cdot 1 \mathrm{M}$ phosphate buffer for $2 \mathrm{~h}$; cells were then washed twice for $10 \mathrm{~min}$ and then for $1 \mathrm{~h}$ in $0.1 \mathrm{M}$ phosphate buffer. Cells were fixed in $1 \% \mathrm{OsO}_{4}$ in $0 \cdot 1 \mathrm{M}$ phosphate buffer for $2 \mathrm{~h}$ and then washed again in the same way. The fixed cells were dehydrated in a graduated acetone series $(70-100 \%)$ and subsequently embedded into the resin. Thin sections were cut with a Reichert model ultracut $S$ ultramicrotome, placed on copper grids and stained with $10 \%(\mathrm{w} / \mathrm{v})$ uranyl acetate and $1 \%(\mathrm{w} / \mathrm{v})$ lead citrate. The stained thin sections were examined by transmission electron microscopy (TEM) and energy-dispersive X-ray spectroscopy (TEM-EDS) with a JEOL model JEM-2000ES at an acceleration voltage of $200 \mathrm{kV}$. For scanning electron microscope observations, cells incubated in liquid SOB medium containing thiosulfate at $25^{\circ} \mathrm{C}$ for 1 day were fixed with $2 \%(\mathrm{v} / \mathrm{v})$ glutaraldehyde in $0 \cdot 1 \mathrm{M}$ phosphate buffer for $2 \mathrm{~h}$. Further preparation steps were conducted according to Yumoto et al. (2001). The cultures were mounted on aluminium stubs and observed under a Hitachi model S-4000 scanning electron microscope at an acceleration voltage of $3 \cdot 5 \mathrm{kV}$.

Analyses of whole-cell fatty acids and isoprenoid quinones were performed as described previously (Yumoto et al., 2001). Genomic DNA for the analysis of $G+C$ content was prepared as described by Marmur (1961). The G+C content $(\mathrm{mol} \%)$ of the genomic DNA was determined by HPLC according to the method of Tamaoka \& Komagata (1984). The levels of DNA relatedness were determined fluorometrically by the method of Ezaki et al. (1989) using photobiotin-labelled DNA probes and microplates. The DNA-DNA hybridization study was conducted only against Halothiobacillus neapolitanus (strain JCM 3861), the type species of the genus Halothiobacillus and most closely related species to strain $S O 07^{\mathrm{T}}$, because $16 \mathrm{~S}$ rRNA gene similarities between strain $\mathrm{SO}^{\mathrm{T}}{ }^{\mathrm{T}}$ and all members of the genus Halothiobacillus are low (less than $89 \%$ ).

PCR amplification, purification of PCR products and 16S rRNA gene sequencing were carried out as described previously (Ito et al., 2004). Phylogenetic inferences were made with the $16 \mathrm{~S}$ rRNA gene sequence database associated with the ARB software package (Ludwig et al., 2004). Phylogenetic trees were then constructed by using the ARB neighbour-joining and maximum-parsimony algorithms. Bootstrap analysis was performed to establish a confidence level for nodes. 16S rRNA gene sequence similarity values were calculated by using the program Similarity_Matrix in the Ribosomal Database Project II (Cole et al., 2003).

Chemolithoautotrophic growth of strain $\mathrm{SO}^{\mathrm{T}}{ }^{\mathrm{T}}$ was observed on sulfide, thiosulfate and elemental sulfur. Growth on thiosulfate reduced the $\mathrm{pH}$ to a minimum of $6 \cdot 0$. The $\mathrm{pH}$ range for growth of strain $\mathrm{SO}_{0} 7^{\mathrm{T}}$ was $6 \cdot 0-9 \cdot 0$, with optimal growth at $\mathrm{pH} 7 \cdot 5$. The temperature range for growth was $15-42{ }^{\circ} \mathrm{C}$, with an optimum growth temperature of $30-34^{\circ} \mathrm{C}$. This strain grew at $\mathrm{NaCl}$ concentrations of $30-180 \mathrm{mM}$. No growth was observed in $230 \mathrm{mM}$ $\mathrm{NaCl}$. Heterotrophic growth was not observed when tested with acetate, formate, propionate or methanol. Anaerobic growth did not occur in the presence of any organic or inorganic substrates when nitrate was used as an electron acceptor. No fermentative growth was observed on methanol, formate, acetate or propionate. Mixotrophic tests on thiosulfate with formate, acetate or propionate revealed growth inhibition.

Colonies of strain $\mathrm{SO}^{\mathrm{T}} 7^{\mathrm{T}}$ grown on solid $\mathrm{SOB}$ medium containing thiosulfate were $0.5-1.0 \mathrm{~mm}$ in diameter, white-coloured and lens-shaped. The colour and morphology of the colonies did not change during incubation for 5 days. The isolate was Gram-negative, catalase-positive and oxidase-positive. Cells were rodshaped $(0 \cdot 5-0 \cdot 8 \times 1 \cdot 0-2 \cdot 0 \mu \mathrm{m})$, non-spore-forming and 


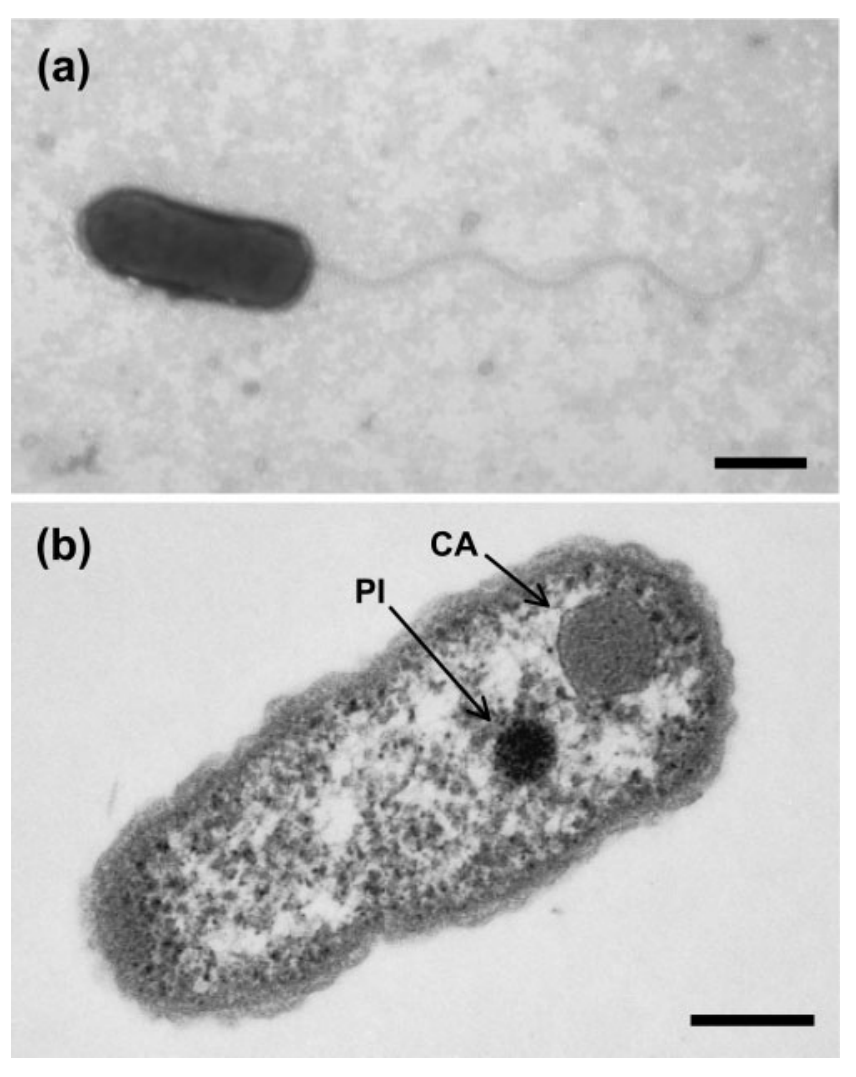

Fig. 1. Transmission electron micrographs of cells of strain SO07 ${ }^{\top}$. (a) Negatively stained cell showing the single polar flagellum (bar, $0.4 \mu \mathrm{m}$ ). (b) An ultrathin section of a cell stained with uranyl acetate and lead citrate (bar, $0.2 \mu \mathrm{m}$ ). Cells in (a) and (b) were grown on thiosulfate and sulfide, respectively. CA, carboxysome; $\mathrm{Pl}$, polyphosphate-like inclusion. The carboxysome was enveloped by a thin membrane-like structure.

motile by means of a single polar flagellum (Fig. 1). Structure of the cell wall was a typical Gram-negativestained type (Fig. 1b). Scanning electron microscope observations revealed that the cells had large surface areas with cobble-like structures on their surfaces (Fig. 2). Carboxysome-like inclusions were observed in the cells (Fig. 1b). The number of carboxysome-like inclusions in exponential-growth-phase cells incubated with thiosulfate averaged about $6 \pm 3(n=20)$ per cell, whereas that with sulfide was $2 \pm 1(n=20)$ per cell. It has been reported that the number of carboxysomes per cell in Thiomonas intermedia (formerly Thiobacillus intermedius) is proportional to the specific activity of ribulose-1,5-bisphosphate carboxylase (Purohit et al., 1976). The higher number of carboxysomes in cells incubated with thiosulfate may explain the higher maximum specific growth rate on thiosulfate of $0 \cdot 41 \mathrm{~h}^{-1}$, compared with $0 \cdot 30 \mathrm{~h}^{-1}$ on sulfide. Storage of polyphosphate-like inclusions was observed when strain $\mathrm{SO}^{\mathrm{T}} \mathrm{T}^{\mathrm{T}}$ was grown with sulfide as electron donor (Fig. 1b). The polyphosphate-like inclusions contained phosphorous, which was determined by TEM-EDS analysis.

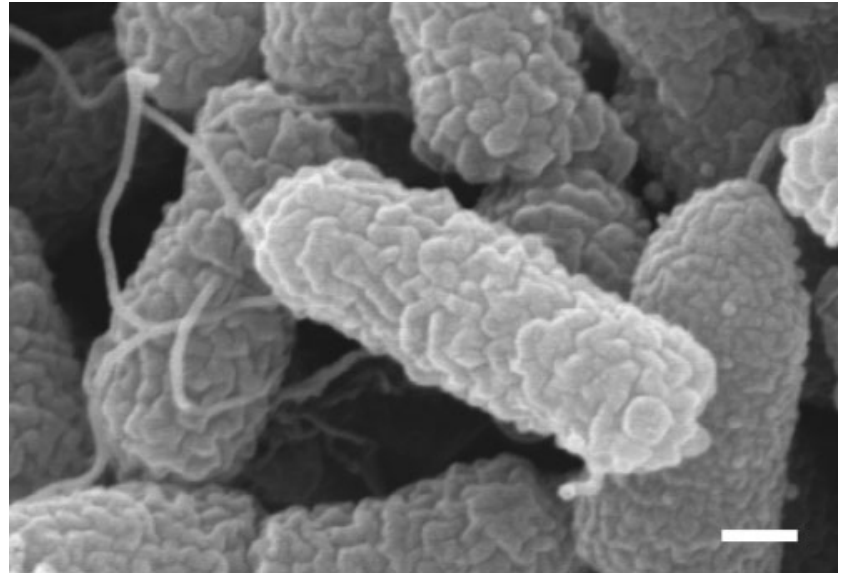

Fig. 2. Scanning electron micrograph of cells of strain $S O 07^{\top}$ grown on SOB medium containing thiosulfate. Bar, $0.2 \mu \mathrm{m}$.

Analysis of quinone compounds revealed Q- 8 to be the major isoprenoid quinone. Predominant cellular fatty acids of strain $\mathrm{SO}^{\mathrm{T}}$ were $\mathrm{C}_{12: 0}(2 \%), \mathrm{C}_{16: 0}(19 \%)$, $\mathrm{C}_{18: 0}(16 \%), \mathrm{C}_{16: 1}(30 \%)$ and $\mathrm{C}_{18: 1}(31 \%)$. The DNA $\mathrm{G}+\mathrm{C}$ content of strain $\mathrm{SO} 7^{\mathrm{T}}$ was $47 \cdot 1 \mathrm{~mol} \%$. The DNADNA relatedness between strain $\mathrm{SO}^{\mathrm{T}}$ and $H$. neapolitanus JCM 3861 was less than $2 \%$.

Comparison of $16 \mathrm{~S}$ rRNA gene sequences revealed that strain $\mathrm{SO}^{\mathrm{T}}{ }^{\mathrm{T}}$ formed a monophyletic group within the $\gamma$ Proteobacteria, as supported by high bootstrap values (Fig. 3), and can clearly be distinguished from members of the genus Halothiobacillus (less than $89 \%$ sequence similarity between them). A slightly higher level of $16 \mathrm{~S}$ rRNA gene sequence similarity was observed between strain $\mathrm{SO}^{\mathrm{T}} \mathrm{T}^{\mathrm{T}}$ and 'Thiobacillus baregensis' (90\%) than between strain $\mathrm{SO}^{\mathrm{T}} \mathrm{7}^{\mathrm{T}}$ and members of the genus Halothiobacillus (87-89\%). High sequence similarities were obtained between strain $\mathrm{SO}^{\mathrm{T}}$ and partial sequences of the asyet-uncultured bacterial clones SRang2.5 (98\%) and bacteriap48 $(97 \%)$, which were retrieved from sulfurous environments, i.e. Sulphur River in Parker Cave and a muddy hot pool in Kuirau Park, respectively (Angert et al., 1998; Sunna \& Bergquist, 2003). Thus, the ability of these clones to oxidize sulfur could be inferred. Characterization of strain $\mathrm{SO}^{\mathrm{T}}{ }^{\mathrm{T}}$ strongly indicated that the cluster including these environmental clones comprised chemolithoautotrophic sulfur-oxidizing bacteria. As in waste-water biofilms, the source of strain SO07 ${ }^{\mathrm{T}}$, oxygen concentrations in these habitats would be low due to the relatively high concentrations of organic matter and sulfide.

Strain $\mathrm{SO} 07^{\mathrm{T}}$ shares the same phenotypic properties as members of the genus Halothiobacillus: mesophilic, neutrophilic and obligately chemolithoautotrophic, obtaining energy from reduced inorganic sulfur compounds. Both strain $\mathrm{SO}^{\mathrm{T}}$ and members of the genus Halothiobacillus contain ubiquinone Q-8 as the major isoprenoid quinone. 


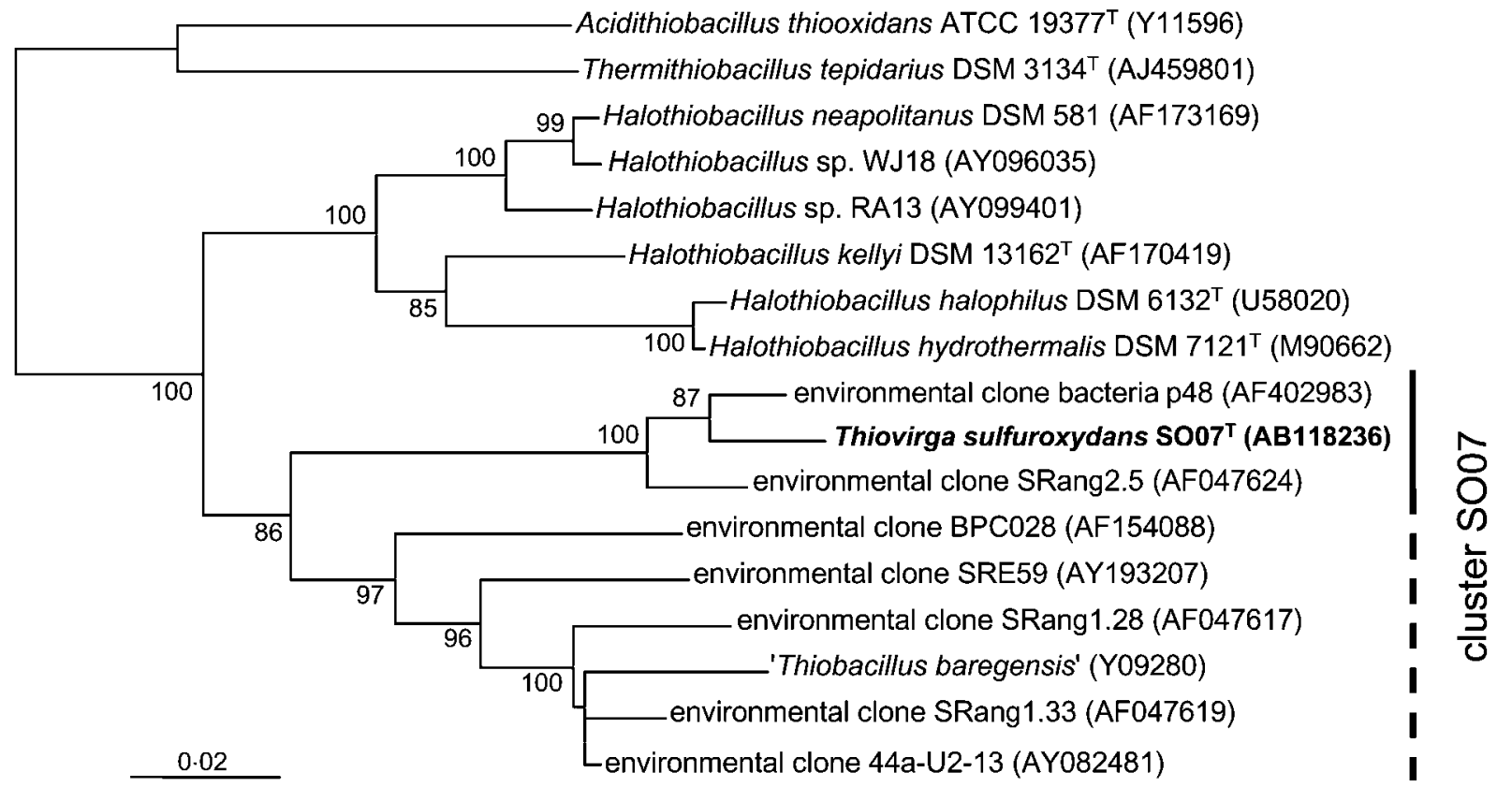

Fig. 3. Phylogenetic tree based on analysis of $16 \mathrm{~S}$ rRNA gene sequences of strain $\mathrm{SO}^{\mathrm{T}} 7^{\top}$ and representative species of some distantly related sulfur-oxidizing genera of the $\gamma$-Proteobacteria, constructed by using the neighbour-joining method. Nearly complete 16S rRNA gene sequences were used. Numbers at the nodes represent bootstrap values. Bar, 0.02 inferred nucleotide substitutions per nucleotide position. Further isolation and characterization of bacteria represented by environmental clones, including BPC028, SRE59 or SRang1.28, might expand the coverage of cluster SO07, as shown by the dashed line.

The presence of carboxysome-like inclusions in the cells of strain $\mathrm{SO} 07^{\mathrm{T}}$ has also been described for $H$. neapolitanus by Shively et al. (1973). In contrast to members of the genus Halothiobacillus, strain $\mathrm{SO}^{\mathrm{T}}$ did not require $\mathrm{NaCl}$ for growth and the growth of this strain was completely inhibited at $\mathrm{NaCl}$ concentrations greater than $180 \mathrm{mM}$
(Table 1). In fact, all Halothiobacillus species have high $\mathrm{NaCl}$ tolerances (more than $860 \mathrm{mM} \mathrm{NaCl}$ and up to $4000 \mathrm{mM}$ ) and their optimal $\mathrm{NaCl}$ concentrations for growth are relatively high (more than $400 \mathrm{mM} \mathrm{NaCl}$ ) (Kelly \& Wood, 2000; Sievert et al., 2000). These distinctive characteristics of strain $\mathrm{SO}^{\mathrm{T}}$ allow it to be differentiated

Table 1. Main phenotypic characteristics that differentiate strain $S O 07^{\top}$ from mesophilic, neutrophilic and chemolithoautotrophic sulfur-oxidizing bacteria belonging to the $\gamma$-Proteobacteria

Species: 1, Thiovirga sulfuroxydans $\mathrm{SO}^{\mathrm{T}}$; 2, Halothiobacillus neapolitanus DSM $15147^{\mathrm{T}} ; 3$, Halothiobacillus hydrothermalis DSM $7121^{\mathrm{T}}$; 4 , Halothiobacillus halophilus DSM $6132^{\mathrm{T}}$; 5, Halothiobacillus kellyi DSM $13162^{\mathrm{T}}$; 6, Thiobacillus sp. W5; 7, Thiomicrospira frisia DSM $12351^{\mathrm{T}}$; 8, Thiomicrospira chilensis DSM $12352^{\mathrm{T}}$. All species were obligately chemolithoautotrophic, mesophilic, neutrophilic motile rods and oxidized thiosulfate, sulfur and sulfide. Data from Kelly \& Wood (2000), Sievert et al. (2000) and Brinkhoff et al. (1999a, b).

\begin{tabular}{|c|c|c|c|c|c|c|c|c|}
\hline Characteristic & 1 & 2 & 3 & 4 & 5 & 6 & 7 & 8 \\
\hline \multicolumn{9}{|l|}{ Conditions for optimum growth: } \\
\hline Temp. $\left({ }^{\circ} \mathrm{C}\right)$ & $30-34$ & $28-32$ & $35-40$ & $30-32$ & $37-42$ & $25-30$ & $32-35$ & $32-37$ \\
\hline $\mathrm{pH}$ & $7 \cdot 5$ & $6 \cdot 5-6 \cdot 9$ & $7 \cdot 5-8 \cdot 0$ & $7 \cdot 0-7 \cdot 3$ & $6 \cdot 5$ & $7 \cdot 0-7 \cdot 5$ & $6 \cdot 5$ & $7 \cdot 0$ \\
\hline $\mathrm{NaCl}(\mathrm{mM})$ & 0 & ND & 430 & $800-1000$ & $400-500$ & ND & 470 & 470 \\
\hline Upper $\mathrm{NaCl}$ concn for growth $(\mathrm{mM})$ & 180 & $>860$ & 2000 & 4000 & 2500 & ND & 1240 & 1240 \\
\hline Major fatty acids & $\begin{array}{c}\mathrm{C}_{12: 0}, \mathrm{C}_{16: 0}, \mathrm{C}_{18: 0} \\
\mathrm{C}_{16: 1}, \mathrm{C}_{18: 1}\end{array}$ & $\begin{array}{c}\mathrm{C}_{16: 0}, \mathrm{C}_{16: 1}, \mathrm{C}_{18: 1} \\
\mathrm{C}_{17} \text { cyc., } \mathrm{C}_{19} \text { cyc. }\end{array}$ & ND & ND & ND & ND & ND & ND \\
\hline DNA G $+C$ content $(\mathrm{mol} \%)$ & $47 \cdot 1$ & $56 \cdot 0$ & $67 \cdot 4$ & $64 \cdot 2$ & $62 \cdot 0$ & $56 \cdot 0$ & $39 \cdot 6$ & $49 \cdot 9$ \\
\hline
\end{tabular}

ND, Not determined. 
from Halothiobacillus species. Strain $\mathrm{SO} 07^{\mathrm{T}}$ may be regarded as a freshwater species. Analysis of nearly complete $16 \mathrm{~S}$ rRNA gene sequences revealed low levels of similarity (87-89\%) between strain $\mathrm{SO}^{\mathrm{T}}$ and Halothiobacillus species. The level of DNA-DNA hybridization between strain $\mathrm{SO}^{\mathrm{T}} \mathrm{7}^{\mathrm{T}}$ and $H$. neapolitanus was less than $2 \%$. In addition, the DNA $\mathrm{G}+\mathrm{C}$ content of strain $\mathrm{SO} 07^{\mathrm{T}}$ $(47 \cdot 1 \mathrm{~mol} \%)$ is significantly lower than those of Halothiobacillus species, i.e. 56 $0-67 \cdot 4 \mathrm{~mol} \%$ (Kelly \& Wood, 2000; Sievert et al., 2000). Because of the distinct differences in phylogeny, chemotaxonomy and the requirement for and tolerance of $\mathrm{NaCl}$ between strain $\mathrm{SO} 07^{\mathrm{T}}$ and members of the genus Halothiobacillus, it is proposed that strain $\mathrm{SO}^{\mathrm{T}}{ }^{\mathrm{T}}$ represents the type strain of the type species of a new genus, Thiovirga sulfuroxydans gen. nov., sp. nov.

\section{Description of Thiovirga gen. nov.}

Thiovirga (Thi.o.vir'ga. Gr. n. thion sulfur; L. fem. n. virga rod; N.L. fem n. Thiovirga sulfur rod).

Obligately chemolithoautotrophic, Gram-negative rod. Motile, obtaining energy from reduced inorganic sulfur compounds. Oxidase- and catalase-positive. No spore formation. No anaerobic or heterotrophic growth observed. Cells contain carboxysome inclusions. Cells store polyphosphate inclusions when grown on sulfide. Contains ubiquinone Q-8. Major fatty acids are $\mathrm{C}_{16: 0}, \mathrm{C}_{18: 0}, \mathrm{C}_{16: 1}$ and $\mathrm{C}_{18: 1}$. Member of the $\gamma$-Proteobacteria, which is distantly related to halotolerant sulfur-oxidizing bacteria, the members of the genus Halothiobacillus.

The type species is Thiovirga sulfuroxydans.

\section{Description of Thiovirga sulfuroxydans sp. nov.}

Thiovirga sulfuroxydans (sul.fur.ox'y.dans. L. n. sulfur sulfur; N.L. part. adj. oxydans oxidizing; N.L. part. adj. sulfuroxydans sulfur-oxidizing).

Cells are rod-shaped, $0.5-0 \cdot 8 \times 1 \cdot 0-2 \cdot 0 \mu \mathrm{m}$. Colonies on inorganic medium containing thiosulfate (SOB medium) are white in colour and lens-shaped (diameter of $0.5-1.0 \mathrm{~mm}$ ). Gram-negative. Cells occur singly or in pairs and are motile by single polar flagella. Strictly aerobic. Grows chemolithoautotrophically on thiosulfate, sulfur and sulfide. Nitrate is not used as terminal electron acceptor. No heterotrophic growth occurs. Optimum growth temperature is $30-34^{\circ} \mathrm{C}$; optimum $\mathrm{pH}$ is $7 \cdot 5$; and optimum $\mathrm{NaCl}$ concentration is $30 \mathrm{mM}$. No growth is observed in $\mathrm{NaCl}$ concentrations of more than $180 \mathrm{mM}$ or above $42^{\circ} \mathrm{C}$. Cells contain carboxysome inclusions. Stores polyphosphate inclusions in cells when grown on sulfide. Major isoprenoid quinone is ubiquinone Q-8. Major fatty acids are $\mathrm{C}_{16: 0}(19 \%), \mathrm{C}_{18: 0}(16 \%), \mathrm{C}_{16: 1}(30 \%)$ and $\mathrm{C}_{18: 1}(31 \%)$; $\mathrm{C}_{12: 0}(2 \%)$ is present as a minor fatty acid.

The type strain is $\mathrm{SO}^{\mathrm{T}}{ }^{\mathrm{T}}\left(=\mathrm{JCM} 12417^{\mathrm{T}}=\mathrm{ATCC}\right.$ BAA$\left.1033^{\mathrm{T}}\right)$. The DNA $\mathrm{G}+\mathrm{C}$ content of the type strain is
$47 \cdot 1 \mathrm{~mol} \%$. Isolated from a microaerobic waste-water biofilm at a waste-water treatment plant at Sapporo, Japan.

\section{Acknowledgements}

This work was partially supported by a grant-in-aid (no. 13650593) for Developmental Scientific Research from the Ministry of Education, Science and Culture of Japan. This study was also carried out as a part of 'The Project for Development of Technologies for Analysing and Controlling the Mechanism of Biodegrading and Processing', which was entrusted by the New Energy and Industrial Technology Development Organization (NEDO). T. I. is supported by a research fellowship of the Japan Society for the Promotion of Science.

\section{References}

Angert, E. R., Northup, D. E., Reysenbach, A.-L., Peek, A. S., Goebel, B. M. \& Pace, N. R. (1998). Molecular phylogenetic analysis of a bacterial community in Sulphur River, Parker Cave, Kentucky. Am Mineralogist 83, 1583-1592.

Benson, D. A., Karsch-Mizrachi, I., Lipman, D. J., Ostell, J. \& Wheeler, D. L. (2003). GenBank. Nucleic Acids Res 31, $23-27$.

Brinkhoff, T., Muyzer, G., Wirsen, C. O. \& Kuever, J. (1999a). Thiomicrospira kuenenii sp. nov. and Thiomicrospira frisia sp. nov., two mesophilic obligately chemolithoautotrophic sulfur-oxidizing bacteria isolated from an intertidal mud flat. Int J Syst Bacteriol 49, 385-392.

Brinkhoff, T., Muyzer, G., Wirsen, C. O. \& Kuever, J. (1999b). Thiomicrospira chilensis sp. nov., a mesophilic obligately chemolithoautotrophic sulfur-oxidizing bacterium isolated from a Thioploca mat. Int J Syst Bacteriol 49, 875-879.

Cline, J. D. (1969). Spectrophotometric determination of hydrogen sulfide in natural waters. Limnol Oceanogr 14, 454-458.

Cole, J. R., Chai, B., Marsh, T. L. \& 8 other authors (2003). The Ribosomal Database Project (RDP-II): previewing a new autoaligner that allows regular updates and the new prokaryotic taxonomy. Nucleic Acids Res 31, 442-443.

Ezaki, T., Hashimoto, Y. \& Yabuuchi, E. (1989). Fluorometric deoxyribonucleic acid-deoxyribonucleic acid hybridization in microdilution wells as an alternative to membrane filter hybridization in which radioisotopes are used to determine genetic relatedness among bacterial strains. Int J Syst Bacteriol 39, 224-229.

Hobbie, J. E., Daley, R. J. \& Jasper, S. (1977). Use of nucleopore filters for counting bacteria by fluorescence microscopy. Appl Environ Microbiol 33, 1225-1228.

Ito, T., Sugita, K. \& Okabe, S. (2004). Isolation, characterization, and in situ detection of a novel chemolithoautotrophic sulfuroxidizing bacterium in wastewater biofilms growing under microaerophilic conditions. Appl Environ Microbiol 70, 3122-3129.

Kelly, D. P. \& Wood, A. P. (2000). Reclassification of some species of Thiobacillus to the newly designated genera Acidithiobacillus gen. nov., Halothiobacillus gen. nov. and Thermithiobacillus gen. nov. Int $J$ Syst Evol Microbiol 50, 511-516.

Kuenen, J. G., Robertson, L. A. \& Tuovinen, O. H. (1991). The genera Thiobacillus, Thiomicrospira, and Thiosphaera. In The Prokaryotes, 2nd edn, vol. 3, pp. 2638-2657. Edited by A. Balows, H. G. Truper, M. Dworkin, W. Harder \& K.-H. Schleifer. New York: Springer.

Ludwig, W., Strunk, O., Westram, R. \& 29 other authors (2004). ARB: a software environment for sequence data. Nucleic Acids Res 32, 1363-1371. 
Marmur, J. (1961). A procedure for the isolation of deoxyribonucleic acid from microorganisms. J Mol Biol 3, 208-218.

Purohit, K., McFadden, B. A. \& Shaykh, M. M. (1976). D-Ribulose1,5-bisphosphate carboxylase and polyhedral inclusion bodies in Thiobacillus intermedius. J Bacteriol 127, 516-522.

Shively, J. M., Ball, F. L. \& Kline, B. W. (1973). Electron microscopy of the carboxysomes (polyhedral bodies) of Thiobacillus neapolitanus. J Bacteriol 116, 1405-1411.

Sievert, S. M., Heidorn, T. \& Kuever, J. (2000). Halothiobacillus kellyi sp. nov., a mesophilic, obligately chemolithoautotrophic, sulfur-oxidizing bacterium isolated from a shallow-water hydrothermal vent in the Aegean Sea, and emended description of the genus Halothiobacillus. Int J Syst Evol Microbiol 50, 1229-1237.

Sunna, A. \& Bergquist, P. L. (2003). A gene encoding a novel extremely thermostable $1,4-\beta$-xylanase isolated directly from an environmental DNA sample. Extremophiles 7, 63-70.

Tamaoka, J. \& Komagata, K. (1984). Determination of DNA base composition by reversed-phase high-performance liquid chromatography. FEMS Microbiol Lett 25, 125-128.

Yumoto, I., Yamazaki, K., Hishinuma, M., Nodasaka, Y., Suemori, A., Nakajima, K., Inoue, N. \& Kawasaki, K. (2001). Pseudomonas alcaliphila sp. nov., a novel facultatively psychrophilic alkaliphile isolated from seawater. Int J Syst Evol Microbiol 51, 349-355. 